\title{
Can Two-Port Hand Assisted Laparoscopic Appendectomy be a Good Alternative to Open and Three Port Appendectomies?
}

\section{Çift Port El Yardımlı Laparoskopik Apendektomi, Açık ve Üç Port Apendektomiye lyi Bir Alternatif Olabilir mi?}

\author{
Turgut Dönmez, Oğuzhan Sunamak*, Adnan Hut**, Muzaffer Akıncı**, \\ Ahmet Kocakuşak**, Hüseyin Avaroğlu, Doğan Yıldırım**, Sina Ferahman*** \\ Lütfiye Nuri Burat State Hospital, Clinic of General Surgery, Istanbul, Turkey \\ *Haydarpaşa Training and Research Hospital, Clinic of General Surgery, Istanbul, Turkey \\ **Haseki Training and Research Hospital, Clinic of General Surgery, Istanbul, Turkey \\ ***istanbul University Cerrahpaşa Faculty of Medicine, Department of General Surgery, Istanbul, Turkey
}

\section{Abstract}

\begin{abstract}
Aim: Laparoscopic appendectomy has been performed in increasing numbers since it was first described in 1980. Nowadays, it is being performed by using the three-, two- and single-port methods. We performed two-port hand-assisted laparoscopic appendectomies and reported our prospective results.
\end{abstract}

Methods: Forty consecutive patients (27 males and 13 females) with acute appendicitis according to physical examination and ultrasonography findings were operated on with two-port handassisted laparoscopic appendectomy by the same surgeon between 2011 and 2015. Five-mm (subumbilical) trocar for endoscopy and 10-mm (McBurney) trocar were used to perform appendectomy. The appendix was taken out through the lumen of the 10-mm trocar and ligated extracorporeally and appendectomy was completed extracorporeally. If necessary, another 5-mm trocar was also placed at the left lower quadrant in difficult cases and appendectomy was completed in the same way as described.

Results: The mean duration of the surgical procedure was 23.175 minutes and the mean duration of the whole operation was 41.3 minutes. All the patients except for one were discharged on the first postoperative day. A third port was necessary in 8 (8/40) cases. The mean hospitalization time was 1.075 days.
Amaç: Laparoskopik apendektomi tarif edildiği 1980 tarihinden beri artan sıklıkta uygulanmaktadır. Günümüzde olgularda; üç, iki ve tek portlu metodlar kullanılmaktadır. Genel cerrahi kliniğimizde çift port laparoskopi yardımlı apendektomi yaptığımız olgulardan elde ettiğimiz prospektif veriler sunuldu.

Yöntemler: Acil servisimize fizik muayene ve ultrasonografi sonuçlarına göre akut apandisit tanısı ile ardışık başvuran 40 hasta (27 erkek ve 13 kadın) çift port el yardımlı laparoskopik apendektomi metodu ile aynı cerrah tarafından 2011-2015 tarihleri arasında ameliyat edildi. Endoskopi için $5 \mathrm{~mm}$ (subumblikal) ve apendektomi için $10 \mathrm{~mm}$ (McBurney) çalışma trokarları kullanıldı. Apendix $10 \mathrm{~mm}$ trokar içinden çıkarılıp batın dışında bağlandı ve kesildi. Gerektiğinde zor olgularda 5 mm'lik bir trokar da sol alt kadrandan girilerek apendektomi aynı şekilde gerçekleştirildi.

Bulgular: Ortalama cerrahi girişim süresi 23,175 dakika, tüm prosedürün süresi ise 41,3 dakika idi. Bir kişi hariç hastaların tamamı ameliyat sonrası birinci gün taburcu edildi. Üçüncü port gerekliliği 8 (8/40) olguda oluştu. Ortalama hastanede kalış süresi ise 1,075 gün idi.

Sonuç: Çift port laparoskopi yardımlı apendektomi tekniği hem açık, hem de laparoskopik ameliyatların avantajlarını intiva etmekte olup
Address for Correspondence/Yazışma Adresi: Ahmet Kocakuşak Haseki Training and Research Hospital, Clinic of General Surgery, İstanbul, Turkey Phone: +90 2163688774 E-mail: ahmetkocakusak@yahoo.com Received/Geliş Tarihi: 29 January 2016 Accepted/Kabul Tarihi: 05 March 2016
The Medical Bulletin of Haseki Training and Research Hospital, published by Galenos Publishing. Haseki Tıp Bülteni, Galenos Yayınevi tarafından basılmıştır. 
Conclusion: The two-port hand-assisted laparoscopic technique combines both the advantages of open and laparoscopic surgeries, providing a shorter operation time and hospital stay. In difficult cases, one should not hesitate to insert a third 5-mm port and complete the assisted appendectomy.

Keywords: Laparoscopic surgery, appendectomy, hand assisted laparoscopic appendectomy

\section{Introduction}

Laparoscopic appendectomy has been performed in increasing numbers since it was first introduced by Semm in 1980 (1). The procedures have been done by using the three-port and, nowadays, the two-port and single-port methods have also been introduced. Due to cosmetic concerns, decreased number of ports has been used. However, the single-port technique, single incision laparoscopic appendectomy, takes longer compared to the two- and three-port ones (2). We performed two-port hand-assisted laparoscopic appendectomy and reported our results.

\section{Methods}

Forty consecutive patients (27 males and 13 females) were operated on with acute appendicitis according to physical examination and ultrasonography results with two-port hand-assisted laparoscopic appendectomy in the surgery clinic of Lütfiye Nuri Burat State Hospital during the night shifts of a defined surgeon between 2011 and 2015. To discard the effects of different surgical skills and habits, all appendectomies were performed by the same surgeon. Although any suspicion of a retrocecal appendicitis according to physical examination or imaging modalities was a contraindication for the selection of the patients for the study, retrocecal cases were finished by the help of a third port if the situation was detected intraoperatively. The mean age of the patients was 20.8 years (range: 18-26). All the patients were of American Society of Anesthesiologists score one and the mean leukocyte count was 13290/ $\mathrm{mm}^{3}$ (range: 9800-16400). The mean height was $172.2 \mathrm{~cm}$ (range: 165-182) and the mean weight was $59.875 \mathrm{~kg}$ (range: 51-74). A veress needle was introduced into the subumbilical area and following the established $\mathrm{CO}_{2}$ pneumoperitoneum consisting of $15 \mathrm{mmHg}$, a $5 \mathrm{~mm}$ trocar was inserted into the abdominal cavity and a 30 degree 5-mm endoscope was used to visualize the appendix. If the appendix was not perforated, not retrocecal or no adhesion was present, then only a $10-\mathrm{mm}$ trocar was inserted into the abdomen at McBurney's point; the appendix was grasped on the tip, pneumoperitoneum was deflated and the appendix was daha kısa operasyon ve hastanede kalış süresi sağlamaktadır. Zor olgularda ise üçüncü bir $(5 \mathrm{~mm})$ portun yerleştirilerek operasyonun planlandığı şekilde sonlandırılmasından çekinilmemelidir.

Anahtar Sözcükler: Laparoskopik cerrahi, apendektomi, el yardımlı laparoskopik apendektomi

taken out of the abdomen through this trocar by the help of a grasper (Figure 1, 2 and 3). Then, the mesoappendix and the root of the appendix were ligated with 2/0 Vicryl ${ }^{\circledR}$ extracorporeally and, appendectomy was completed. The appendix stump was then reduced into the abdomen, and following the bleeding control, the trocars were removed; the fascia at the subumbilical port point was sutured and the skin was closed primarily. In eight of cases, a third 5-mm port had to be inserted into the abdomen due to adhesions and retrocecal location of the appendix at the left lower quadrant, but appendectomy was completed in a similar way (Haseki Ethics Committee approval date and number: $22^{\text {nd }}$ July 2015, No: 238).

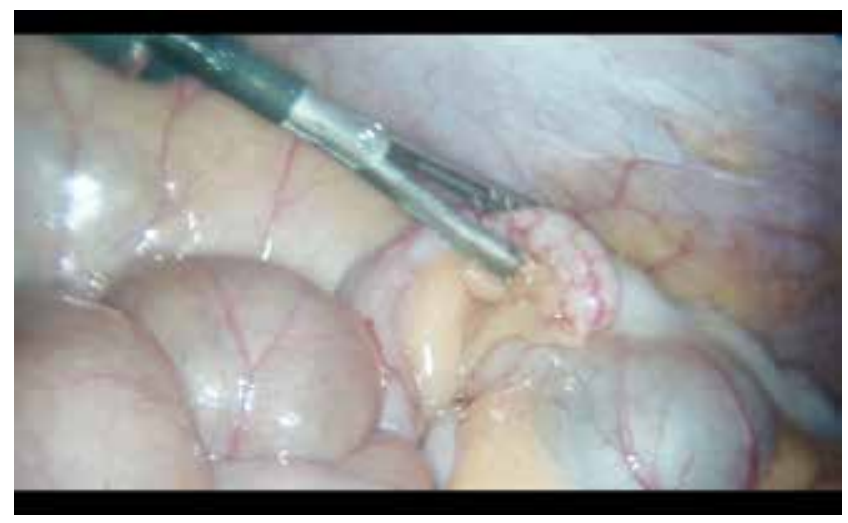

Figure 1. Grasping of appendix

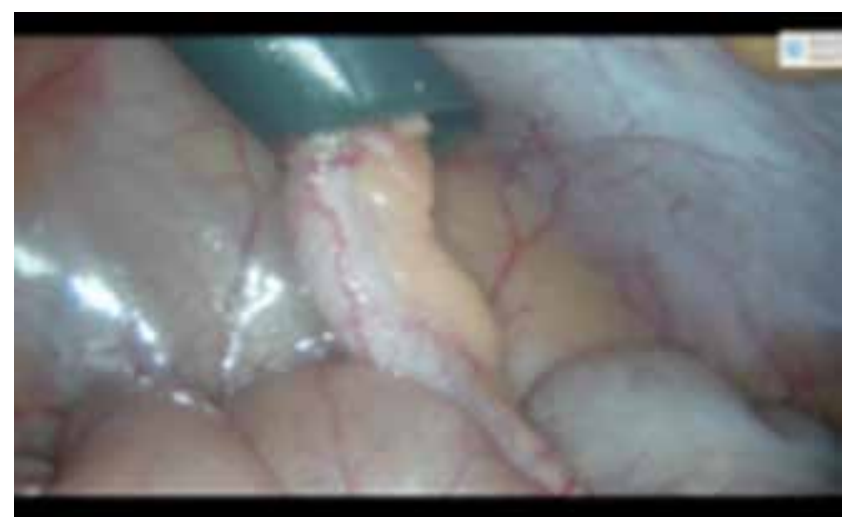

Figure 2. Suction and removal of appendix through $10 \mathrm{~mm}$ trocar 


\section{Results}

The mean duration of the surgical procedure was 23.175 minutes (range: 17-38) and the mean duration of the operation was 41.3 minutes (range: 32-60).

Ultrasonography detected appendicitis in 30 patients and computed tomography scan in the remaining ten. All the operations were performed under general anesthesia. Postoperatively, acetaminophen perfusion analgesia was used three times a day and stopped on the first postoperative day.

In one patient, a trocar port site infection developed $(2.5 \%)$ and the patient was discharged from the hospital on the second postoperative day and healed with a 10day course of a $1^{\text {st }}$ generation cephalosporin. The mean hospitalization time was 1.07 days. In eight patients, a third port was needed. In four patients, a drain was placed at the appendicitis region because of localized fluid collection and was removed on the first postoperative day.

\section{Discussion}

Traditionally, three-port laparoscopic appendectomy has been used since laparoscopic appendectomy was first performed. Though the single-port incision laparoscopic appendectomy (SILA) has been getting popular, it takes longer compared to three-port one. Moreover, it has been reported to necessitate more analgesic use postoperatively (2). In a study reported by Yagnik et al., (3) the mean age of the patients of two-port group was 22.67 years. Our patients were also near to that age group. In this study, the mean operative time was 35.74 minutes, which was comparable to that reported in a study done by El-Gohary and El-Marsafawy, (4) (34.4 minutes). Though our total operation time was a little bit longer, surgical procedure duration was shorter. In a study comparing SILA and three port, operation duration was found to be 43.63 vs. 40.95 minutes $(p=0.29)(5)$. Our mean duration of the operation was also 41.3 minutes, correlating with these results. Yagnik et al., (3) reported 43.94 and 59.65 minutes,

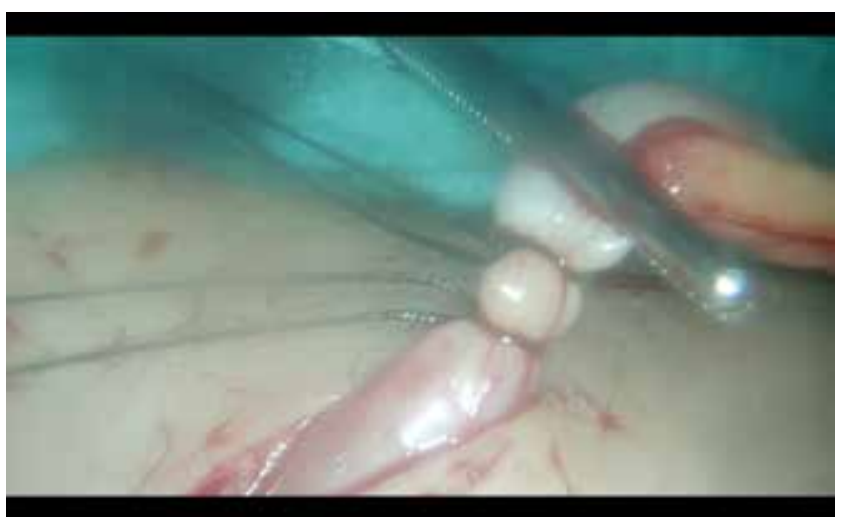

Figure 3. Extracorporeal tying of appendix respectively. Contrary to other studies mentioned above, to maintain randomization, we did not exclude cases with retrocecal localization and adhesion; hence, we had to use a third port in such eight cases, but still our operation time was short. Adhikary et al., (6) have reported a mean operative time of 23.3 minutes. Though longer than this, the mean duration of the surgical procedure for our cases was 23.175 minutes. The average length of hospital stay was 1.07 days in our study and it was shorter compared to that reported in studies by El-Gohary and El-Marsafawy, (4) (3.4 days) and Adhikary et al., (6) (2.4 days). Yagnik et al. (3), found the length of hospital stay to be 1.93 days for two-port methods. In that study, this period was 3.02 days for open and 2.26 days for three-port and, clearly significantly longer for the open one. Two- and three-port techniques were found to be advantageous compared to the open one in terms of hospitalization time in that study. Single incision laparoscopic appendectomy technique has been reported to associate with a shorter hospitalization period compared to three-port one, (1.36 days after SILA and 2.36 days after three-port appendectomy) (7); 1.07 days of hospital stay in our study showed a good correlation with that of SILA. Actually, metaanalyses on SILA failed to show such an advantage on hospitalization period and reported that SILA was associated with a higher pain score (2). Our patients did not need any additional analgesics after the day of operation. Two-port laparoscopic-assisted appendectomy also gave us the advantage of making extracorporeal tying and, thus, shortening the surgery period. We did not try intracorporeal tying because our time advantage could have been vanished (8). Tactile sensation is an essential surgical tool and may encourage less experienced colleagues to perform more complex surgical interventions. The researchers claim that the hand-port device could be a useful tool in all types of benign and malign colorectal surgeries. Randomized trials are necessary to describe the benefits of the hand-assisted techniques (9-11). The extracorporeal technique of appendectomy can be performed as safely and efficiently as the open and full laparoscopic techniques (12-15). We had only one trocar site infection (2.5\%) which was comparable to those of other studies which was in a range of $0 \%$ to $10 \%$ (3). In terms of cosmetics results, we used a 5-mm endoscope through a 5-mm subumbilical port, thus, providing a smaller incision. Our other working port(s) were hidden under the underwear.

\section{Conclusion}

In conclusion; two-port hand-assisted laparoscopic technique combines the advantages of both open and laparoscopic surgeries and provides a shorter operation time and hospital stay. In difficult cases, one should not 
hesitate to insert a third 5-mm port and complete the assisted appendectomy.

\section{Ethics}

Ethics Committee Approval: The study were approved by the Local Ethics Committee of Haseki Training and Research Hospital (22 ${ }^{\text {nd }}$ July 2015, No: 238). Informed Consent: Consent form was filled out by all participants.

Peer-review: Externally peer-reviewed.

\section{Authorship Contributions}

Surgical and Medical Practices: Turgut Dönmez, Oğuzhan Sunamak. Concept: Oğuzhan Sunamak, Adnan Hut. Design: Muzaffer Akıncı, Ahmet Kocakuşak. Data Collection or Processing: Hüseyin Avaroğlu, Doğan Yıldırım. Analysis or Interpretation: Doğan Yıldırım, Sina Ferahman. Literature Search: Hüseyin Avaroğlu, Sina Ferahman, Muzaffer Akıncı. Writing: Ahmet Kocakuşak, Adnan Hut, Turgut Dönmez.

Conflict of Interest: No conflict of interest was declared by the authors.

Financial Disclosure: The authors declared that this study has received no financial support.

\section{References}

1. Semm K. Endoscopic appendectomy. Endoscopy 1983;15:5964.

2. Xue C, Lin B, Huang $Z$, et al. Single-incision laparoscopic appendectomy versus conventional 3-port laparoscopic appendectomy for appendicitis: an updated meta-analysis of randomized controlled trials. Surg Today 2015;45:1179-86.

3. Yagnik VD, Rathod JB, Phatak AG. A retrospective study of two-port appendectomy and its comparison with open appendectomy and three-port appendectomy. Saudi J Gastroenterol 2010;16:268-71.
4. El-Gohary MA, El-Marsafawy M. Port-exteriorization appendectomy (PEA): a preliminary report. Pediatr Surg Int 2001;17:39-41.

5. Buckley FP, 3rd, Vassaur H, Monsivais S, et al. Single-incision laparoscopic appendectomy versus traditional three-port laparoscopic appendectomy: an analysis of outcomes at a single institution. Surg Endosc 2014;28:626-30.

6. Adhikary S, Tyagi S, Sapkota G, et al. Port exteriorization appendectomy: is it the future? Nepal Med Coll J 2008; 10:30-4.

7. Chow A, Purkayastha S, Nehme J, et al. Single incision laparoscopic surgery for appendicectomy: a retrospective comparative analysis. Surg Endosc 2010;24:2567-74.

8. Panait L, Bell RL, Duffy AJ, et al. Two-port laparoscopic appendectomy: minimizing the minimally invasive approach. J Surg Res 2009;153:167-71.

9. Schiedeck TH, Roblick UJ, Dupree HJ, et al. [Hand port-assisted laparoscopic surgery]. Zentralbl Chir 2001;126:243-7.

10. Kaban GK, Czerniach DR, Litwin DE, et al. Hand-assisted laparoscopic surgery. Surg Technol Int 2003;11:63-70.

11. Romanelli JR, Kelly JJ, Litwin DE. Hand-assisted laparoscopic surgery in the United States: an overview. Semin Laparosc Surg 2001;8:96-103.

12. Golebiewski A, Losin M, Murawski M, et al. One, two or three port appendectomy - a rational approach. Wideochir Inne Tech Maloinwazyjne 2013;8:226-31.

13. Arcovedo R, Barrera H, Reyes HS. Securing the appendiceal stump with the Gea extracorporeal sliding knot during laparoscopic appendectomy is safe and economical. Surg Endosc 2007;21:1764-7.

14. Tekin A, Kurtoglu HC. Video-assisted extracorporeal appendectomy. J Laparoendosc Adv Surg Tech A 2002;12:57-60.

15. Mattioli G, Castagnetti M, Jasonni V. Appendicectomy for simple appendicitis: video-assisted or intracorporeal? J Laparoendosc Adv Surg Tech A 2007;17:478-82. 